\title{
TODAY'S MARKET NEEDS MODERNIZED PROPERTY APPRAISERS ${ }^{1}$
}

\author{
Sabina Źróbek \\ Department of Spatial Analysis and Real Estate Market \\ University of Warmia and Mazury in Olsztyn, Poland \\ e-mail:zrobek@uwm.edu.pl
}

Ewa Kucharska-Stasiak

Faculty of Economics and Sociology

University of Łódź, Poland

e-mail:ewa.kucharska@uni.lodz.pl

\section{Małgorzata Renigier-Biłozor}

Department of Spatial Analysis and Real Estate Market

University of Warmia and Mazury in Olsztyn, Poland

e-mail:malgorzata.renigier@uwm.edu.pl

\begin{abstract}
The article identifies and provides a synthetic overview of various concepts relating to the evolution of the real estate market and property valuation. According to the authors, the processes observed on the real estate market necessitate changes in training programs for property valuers. Real estate appraisers should be able to cope with new consumer expectations and requirements, and they should be well versed in modern technological solutions and analytical tools. The study indicates that, in order to face the challenges of the modern world, the appraisal profession should undergo a paradigm shift to embrace the fact that real estate is a commodity and that globalization is inevitable on the real estate market. Due to the high value of urban areas, a modern specialist determining the value of real estate is particularly needed there. Property valuers should develop new analytical skills, and they should rely on modern data processing tools to collect and process information. Additionally, recent events, including the COVID-19 pandemic, demonstrate that property appraisers should be better prepared for dealing with unprecedented circumstances. The training curricula proposed in this article should increase property valuers' competencies and effectively support real estate market entities and sustainable urban development.
\end{abstract}

Key words: appraisal profession, education, property valuation, real estate market.

JEL Classification: D80, L85, Q01, R00.

Citation: Źróbek, S., Kucharska-Stasiak, E., \& Renigier-Biłozor, M. (2020). Today`s market needs modernized property appraisers. Real Estate Management and Valuation, 28(4), 93-103.

DOI: https://doi.org/10.1515/remav-2020-0034

\section{Introduction}

Many economists are of the opinion that the twilight of capitalism and the rise of a post-industrial information society and a knowledge-based economy will inevitably lead to a civilizational breakthrough. Absolute knowledge is an illusion in an era of rapid change. Imperfect knowledge

1 This work was supported by the National Science Centre [grant number 2019/33/B/HS4/00072] 
economics (Frydman \& Goldberg, 2009) asserts that knowledge is incomplete and fragile, and that it easily becomes obsolete. The modern world is increasingly difficult to understand due to sudden, unexpected and discontinuous changes. The ever increasing change of market changes contributes to economic uncertainty and impermanence. Economic phenomena can no longer be evaluated based on straightforward cause and effect relationships. The behavior of market actors cannot be reliably predicted. Many economic theories need to be redefined to account for these processes. The real estate market is one of the economic sectors whose basic tenets have to be re-examined.

The value of property has to be defined for the purpose of market transactions. The question that arises is whether real estate valuers are adequately prepared to face new challenges and requirements, including in the area of property appraisal (Mazzucato, 2018), new technologies and professional trends that will emerge in the $21^{\text {st }}$ century in the face of dynamic changes on the global market and the real estate market. This article examines the extent to which the curricula of training programs for real estate valuers should be modified to adequately meet modern challenges.

The research objective, research hypothesis and the methodology are described in the second section of this article. The theoretical background and the complexity of the analyzed problem are discussed in the third section. The fourth section (most important in terms of the research objective and hypothesis) proposes new topics of instruction and problems that should be incorporated into training programs for real estate valuers. The relevant conclusions and practical recommendations are formulated in the last section of the article.

\section{Research objective and research hypothesis}

The main aim of this study is to present a profile of a modern real estate valuer who has the required professional competencies and skills. The profile of a modern property appraiser was modeled based on the following assumptions: the contemporary real estate market is characterized by rapid (or even hurried) decision-making, a growing number of mortgages, complex relationships between market actors, diverse expectations and often unjustified (unethical) demands made by clients (short appraisal time, overestimation or underestimation of property value to meet the customers' needs).

The following research hypothesis was formulated in view of the above assumptions: the existing property valuation methods, market analysis tools and the profile of real market valuers and experts should be reconsidered and possibly modified to account for new global challenges. Modern real estate valuers should place greater emphasis on the relationships between market actors and an increasingly complex market environment, and they should rely on modern analytical methods and data processing tools to determine the extent to which these relationships influence the value of property.

The main research methodology applied in this study is a critical analysis of the literature, including research papers on the evolution of the conceptual approach to the real estate market, popular science articles, as well as strictly technical papers on real estate valuation and the appraisal profession. Changes in educational programs for real estate valuers were proposed based on the authors' extensive experience and consultations with market practitioners who were regarded as experts for the needs of the research. The authors were the pioneers of the appraisal profession in Poland in the 1990s. They presently teach postgraduate degree courses in real estate valuation, and are university lecturers. All authors are professionally active, and are certified real estate valuers.

\section{The real estate market as the field of operations of property appraisers}

\subsection{Evolution of the conceptual approach to the real estate market}

The conceptual approach to the real estate market continues to evolve. Various definitions of the real estate market have been proposed by the following economic approaches:

- in neoclassical economics, the real estate market is regarded as a resource allocation mechanism, where demand, supply and price are the three main elements of the real estate market,

- in institutional economics, demand and supply on the real estate market are shaped mainly by environmental factors, including social norms and customs, legal norms and psychological factors,

- in the behavioral approach, the real estate market is analyzed based on consumer behaviors that are strongly rooted in psychological processes.

An approach where the real estate market is defined as a resource allocation mechanism, i.e. a 
simple analysis of the evolution of market components, is not highly useful for property appraisal because it ignores the forces that shape demand, supply and prices, the influence of environmental factors on consumer behavior, as well as market paradoxes. This approach cannot be used to evaluate investment risk and its impact on property value. Neoclassical economics relies on a false assumption that market actors have access to complete knowledge and information and are thus fully able to make effective and optimal decisions.

In the institutional approach, the real estate market is defined as a general set of conditions for the transfer of property rights and the conclusion of agreements that set forth the rights and obligations resulting from property ownership and tenure. This definition does not focus on market transactions, but on the underlying mechanisms and factors that shape demand, supply and price. The institutional approach postulates that both economic and non-economic factors should be taken into account during decision-making on the real estate market. The inclusion of non-economic factors in the analytical model has important implications by undermining the simplistic belief that economic decisions are made rationally. In reality, many market decisions are made by trial and error under the influence of traditions and instincts that shape behavioral patterns. The above implies that market economies can no longer be interpreted solely in the context of market mechanisms that are governed by the forces of supply and demand. Every market is a complex set of institutions and rules which partly determine the outcome of the game, and any change in the rules of the game changes the game itself. The state and its specialized agencies are responsible for implementing these rules and monitoring their observance (Hockuba, 2001). Markets have a unified structure in terms of the traded commodities and market participants because the forces of demand and supply are shaped by market actors. The above implies that the definition of a market extends well beyond market mechanisms which merely reflect the subjective aspects of market performance.

The institutional approach to the real estate market (Ball et al. 1998) is closer to meeting property valuation requirements than the approach postulating that the real estate market is a research allocation mechanism (Keogh \& $D^{\prime}$ Arcy, 1999). The institutional approach relies on multi-level modeling (Keogh \& D'Arcy, 1999). The highest level is represented by the institutional framework which is defined by political, social, economic and legal rules and which establishes the organizational foundations of every society. At the second level, the real estate market itself can be regarded as an institution whose structure, scope and functions are shaped by the characteristic attributes of that market. The real estate market is defined as a set of principles, practices and relationships that create a platform for the use of property and property transactions. The third level is represented by real estate organizations. The mutual relations between these organizations and institutions induce changes on the real estate market. The first three levels in the institutional model create conditions that determine the allocation of resources and explain consumer behaviors. In mainstream economics, the main focus is on the fourth level which carries information about demand, supply and prices.

In the institutional approach, the real estate market is limited by economic factors such as income, demand and purchasing power, as well as institutional factors, both formal and informal. Formal factors are represented by the organizations that exist on the real estate market, including professional organizations, codes of practice, and property rights. Informal factors are more difficult to identify because they embody social attitudes such as respect for ownership, emotional attachment to property, social norms established by religious and cultural systems, and business practices stemming from local customs and traditions. These limitations generate transaction costs, and only some of these costs, such as the costs associated with property appraisal, are measurable. Other costs are largely intangible, including the cost of information, the cost of local protests that delay or compromise development projects, the costs associated with strict conservation requirements, and the costs of proenvironmental lobbying.

The institutional approach offers a more comprehensive platform for predicting market trends and evaluating the economic, political and risks associated with real estate development. Therefore, property appraisals should rely on extensive analyses of market phenomena that are not only limited to real estate transactions, including property prices and rents. These analyses should also cover the market of property users to evaluate the demand for real estate, the availability of financial instruments, the rates of return on property investments, as well as the market of undeveloped property. The prices of land influence development density, and an increase in land prices can exacerbate the disproportions between the value of land and the value of land components. These 
factors affect decisions on new development, changes in land use, and the demolition of existing buildings to clear land for new development.

The behavioral approach to the real estate market focuses directly on consumer behaviors and the underlying psychological factors. This approach is much needed in a dynamically changing world. The mechanisms underpinning the formation of price bubbles cannot be explained by the neoclassical approach which relies on the assumption that anonymous market players make rational decisions and appraise the value of property based on knowledge. The human component is largely disregarded in neoclassical economics, and consumer decision-making processes have been incorporated into the market model only in the institutional approach. The concept of a rational economic man (homo oeconomicus) has been criticized in institutional economics which posits that consumers do not always make rational decisions. Consumers became the focal point of economic analyses in the behavioral approach, which explains human behaviors and decisions under conditions of legal, economic and political uncertainty.

Increasingly sophisticated definitions of the real estate market are being proposed in the face of the growing complexity and variability of economic processes. The new definitions do not eliminate but expand the existing concepts. Institutional and behavioral approaches do not offer alternative definitions, but merely supplement the definitions that are already in place. A broader interpretation of the real estate market significantly expands the scope of the relevant research to include analyses of legal regulations, the performance of institutions that play a regulatory role in social organization, the economic consequences of such regulations, and the factors that drive consumer behavior and decision-making. The behavior and expectations of market players have to be taken into consideration in analyses of markets whose structure is unified in terms of the traded commodities and market participants. Many researchers and practitioners are of the opinion that institutional constraints and behavioral factors should be taken into account in market analyses and property valuation. According to Sarazen (1995), the search for the optimal resource allocation methods cannot rely solely on theoretical assumptions. Social organizations proved to be a powerful force that eliminates all other factors. Consumer behavior needs to be analyzed in the process of determining the market value of real estate investments, namely the highest price that potential buyers are willing to accept (French 2017). Research has revealed that behavioral factors strongly influence property appraisal (Wolverton, 2000; Kishore 2004; Brzezicka \& Wiśniewski, 2014). The character traits of real estate valuers and the anchoring and adjustment heuristic play a significant role in subjective assessments of real estate attributes and simplified selection of comparable sales. Property appraisers are also influenced by environmental factors. According to the recommendations of the Royal Institution of Chartered Surveyors (2002), behavioral factors should be taken into consideration in the valuation process. Psychological variables can complicate objective assessments of real estate attributes which determine the market value of property.

A review of the literature suggests that analyses of the real estate market should place greater emphasis on the interactions between market participants and an increasingly complex reality as well as the extent to which these interactions influence the value of real estate (Barkham, et al., 2017). These requirements pose a considerable challenge for the academic community and professional organizations. The curricula of training programs for property valuers should be modified accordingly to prepare the graduates for a career on a rapidly evolving real estate market.

\subsection{The attributes of the real estate market in the context of property valuation}

The real estate market is characterized by considerable specificity in terms of the traded commodities, services and market participants. The transactions on the real estate market involve a bundle of legal rights to property, including ownership, lease, rent and tenure. The range of market participants is also more diverse than on other markets, and involves not only buyers and sellers, but also owners, lessors and lessees. The structure of the real estate market strongly influences the value of property and valuation methods. The above is well reflected by different approaches to property valuation for mortgage purposes. Some countries rely on the German concept of the mortgage lending value (Der Beleihungswert, 2017) with local modifications (such as Poland), whereas in the United Kingdom, attempts are being made to base mortgages on the future value of property (RICS, 2017). The imperfect character of the real estate market is one of its distinguishing features (Ring \& Dasso, 1989). The real estate market is imperfect due to a relatively small number of buyers and sellers, which enables market participants to considerably influence the price of traded property. The real estate 
market is also characterized by low transparency because most market participants have access to bid prices rather than transaction prices; therefore, the information about the incomes that are produced from real estate investments is limited. Low levels of transparency compromise reliable analyses of the property market. The information on the real estate market is also largely asymmetric - the participants' intentions can be deduced from the offers presented by realtors or the mass media, whereas the prices at which properties are traded are not disclosed. The real price of property is often kept confidential, and not all prices stated in notarial deeds reflect the price that has been actually paid. Some market participants are privy to "insider" knowledge, but they constitute a minority. The imperfect character of the real estate market can also be attributed to the inherently low liquidity of property as well as significant variations in property types.

Low elasticity of demand and supply and low market efficiency also play an important role in the process of property appraisal. The real estate market responds slowly to changes due to low elasticity of demand and supply. A rapid increase in demand can lead to a dramatic rise in property prices, which fuels speculation and contributes to the formation of price bubbles, namely substantial price increases that are not justified by the underlying economic factors. Property appraisals on a volatile or rapidly changing market are burdened by considerable risk and uncertainty. On inefficient markets, current prices do not reflect the actual market conditions or the participants' expectations, and they are often based on historical prices (purchase agreements and lease contracts). The above holds particularly true for properties that have been on the market for a long time as well as prices that have been negotiated on a rapidly changing market. Systematic errors could also be simulated on the real estate market, where the value of property is overestimated in boom periods and underestimated during a market downturn. These phenomena are responsible for conservative responses among market participants and parties to market transactions. On an ineffective market, the value of real estate cannot be inferred solely from the price. External knowledge is required to assess the competitive advantage and unique attributes of property. This knowledge stretches beyond the realm of science and elevates property appraisal to the status of art.

Due to the unique attributes of real estate such as immobility, diversity and durability, competition in most segments of the real estate market tends to be local and strongly restricted to a given region. The real estate market is highly susceptible to local demographic, economic, political and social processes. Local fluctuations reflect the strongest trends on the global (and/or supralocal) real estate market. An analysis of the complex and unique character of the real estate market indicates that unlike on the stock market, the price paid does not always represent the market value of property and that the price of real estate should not be automatically equated with its value. Considerable knowledge and skills are required to correctly identify the above correlations in the property valuation process.

Market phenomena are increasingly difficult to identify in an era of rapid change when extreme and unpredictable events (such as the pandemic-induced crisis) are becoming the new norm, when economic crises increase in frequency and severity, when new information does not broaden our knowledge about the market, and when uncertainty weighs on the global economy. Therefore, the curricula of training programs for property appraisers should be modified to adequately address these challenges.

\section{Modernization of training programs to improve the skills and competencies of real estate valuers}

Real estate constitutes the dominant portion of global assets. According to Savills, the value of global assets reached USD 327 trillion in 2016, and real estate accounted for nearly $60 \%$ of that figure (Savils, 2016). The financial crisis of 2007-2008 emphasized the crucial role of the real estate market in the global economy.

Due to the unique characteristics of the real estate market, limited access to market information, and sudden and unpredictable events that can "infect" the market, such as the COVID-19 pandemic, property valuation and decision-making are burdened by considerable risk and uncertainty (RICS, 2020; TEGoVA, 2020). An analysis of Polish property appraisal reports demonstrated that insufficient market knowledge is the main cause of valuation errors (Kucharska-Stasiak, 2014; Źróbek, et al., 2016). The real estate market has to be analyzed and monitored to minimize the risk of crisis events. Renigier-Biłozor and Biłozor (2016) and Renigier-Biłozor et al. (2019) proposed a decision support system where fuzzy logic decision-making procedures were used to analyze real estate markets.

Technological progress creates new challengers for contemporary real estate valuers. Due to the 
enhancement of technology and increasingly freely available market evidence, many of the steps in the valuation process - data collection, data analysis, and data formatting - are performed by computerized models and the valuation profession is seeing a progressive shift towards automated processes (Grover, 2016; RICS, 2016; Susskind \& Susskind, 2015). Property appraisers often lack the required skills and knowledge to perform increasingly sophisticated market analyses. Many of them feel anxious about losing their jobs and being excluded from the professional community (Zissler, 2016). An analysis of the literature suggests that most research focuses on methods for evaluating the accuracy of property appraisals which could be undermined by limited access to information about recent transactions. The implications of outdated training curricula that do not prepare valuers for modern market challenges and compromise the accuracy of property appraisals are less frequently recognized (Źróbek \& Grzesik, 2013). Effective and immediate solutions are needed to address the above problem. Real estate valuers can significantly contribute to filling the existing knowledge gaps in the decision-making process, not only in developing countries. An analysis of legal regulations concerning land management in many countries indicates that property appraisers assist decisionmakers and politicians in pursuing multidimensional goals of sustainable development.

In the contemporary world, robust property assessments not only regulate land tenure and land management rights, but they also constitute a pillar of effective land administration systems (LAS) and are a source of reliable data for effective and transparent land management policies, both in industrialized and developing nations (Williamson \& Wallace, 2007). According to Blass (2016), the valuation profession will be focused on valuations for the present, present future and future future. The market value will be sufficient in most circumstances for the present, but not for the present future (next 1-2 years) or future future (5-10 years). Wilkinson et al. (2017) examined the issues, threats and challenges facing Australian property valuers and proposed two strategies for action in the longer term:

1. Ongoing development of big data analysis skills.

2. Development of a flexible suite of professional qualifications and educational programs (RICS, 2015; Wilkinson, et al., 2017).

The specific knowledge and skills that are essential on the modern real estate market can be identified based on the results of research studies examining property valuers in Australia (Wilkinson, et al., 2018), the Netherlands (Klamer, et al., 2018), Poland and Lithuania (Źróbek, et al., 2016). The preparation of programs for training and improving the knowledge and skills of real estate professionals is a key task if representatives of these professions are to meet current and future expectations (Hannah, 2006; Hughes \& Hughes, 2013). The requirements for candidates to obtain full qualifications of real estate appraisers are quite strict and often differ from country to country (Lorenz, 2006; Act, 1997; Adair, et al., 2012; Mooya, 2015; Act, 2012). According to some authors, professional development should not be structured as a one-size-fits-all educational program, as the valuation profession, at least in the Netherlands is a heterogenic population that deals with task complexity issues at different levels and in different settings (Klamer, et al., 2018).

In the literature, the skills of real estate valuers are generally divided into two major groups:

1. Hard skills: math, analytical skills, writing.

2. Soft skills: customer service, organizational skills, time management, problem solving skills.

The reliability, honesty and impartiality of property valuations in the context of client-valuer relations were also discussed in the literature (Appraisal Institute, 2013; EVS, 2018; IVS, 2020). Appraisers should strive to maintain the highest standards of ethical conduct regardless on the market situation, but practice has shown that these fundamental principles are often overlooked (Achu, 2013; Kucharska-Stasiak, et al., 2018).

This article proposes changes in the curricula of educational and training programs for real estate valuers based on a review of the literature as well as current market trends gleaned from web resources (Islam 2017). Scientific symposia, professional conferences and the Internet create a global communication platform for real estate valuers and the recipients of the generated reports (RICS, 2002; Report, 2012; Coyle, 2015; Hefferan, 2011; Jacobs, 2019; Savills, 2018). A review of these sources clearly indicates that both analytical and communication skills are essential for coping with complex modern problems and providing high-quality services. Advanced professional training programs are needed to effectively address these goals (Thorne, 2012; Kauko, 2013; Report, 2015; Kucharska-Stasiak \& Źróbek, 2015; Runde, 2015; Zróbek, et al., 2016). The proposed curricula and topics of instruction apply to countries with a well-established valuation profession (licensed and/or certified valuers) and 
standardized educational programs for property appraisers. An analysis of the literature, professional publications and training courses advertised online indicates that most programs aim to impart "traditional" knowledge about the real estate market and the technical parameters of property. The following topics and skills should be incorporated into educational curricula and continuing professional development programs to enable real estate valuers to effectively face modern challenges on a rapidly evolving market:

1. Functional models of real estate markets to promote a better understanding of the mechanisms that underpin market operations.

2. Long-term changes on real estate markets to improve valuers' awareness of the risks associated with investing in different types of property.

3. The influence of external factors (political, economic, financial and social) on the performance of real estate markets to enable valuers to interpret and predict market changes in the process of assessing investment risks and their impact on the value of property.

4. The value of real estate, the history of property valuation models, and the circumstances and mechanisms underpinning their evolution.

5. Investment portfolio theory and property valuation for real estate investment to account for the growing share of institutional investors on the market. The relevant knowledge should include property valuation methods in the investor's country of origin.

6. Property appraisers should be familiar with various methods for analyzing the real estate market, including statistical methods, in order to be able to handle large quantities of market data. Valuers should be able to analyze the market in two dimensions: 1. sale or lease of property (traditional approach), where appraisals are made based on the prices of real estate transactions and rents, and 2. division of the real estate market into the market of property users, financial market, developer market, and the land market. Valuers should be able to assess the risks associated with investment in each of the above segments.

7. Modern valuers should acquire skills related to innovative valuation techniques and decision support systems to increase their effectiveness and competitive advantage. Automated Valuation Solutions involving modern tools such as artificial intelligence (AI), machine learning and geocomputation are among the most popular systems that rely on decision algorithms on the real estate market.

8. Standard valuation procedures may not be applicable under extraordinary circumstances, which is why valuers should be familiar with modern techniques for collecting information on property attributes, in particular geolocation methods where the relevant data can be collected without direct contact. Some countries use hybrid valuation methods which require dedicated procedures and data interpretation techniques.

9. Valuers should be well versed in the methods for assessing various types of property for different purposes, which constitutes a separate field of specialist knowledge in some countries. These methods should enable appraisers to develop a wider range of services and better cope with income uncertainty on a rapidly changing market.

10. Modern valuers should have a working knowledge of at least one foreign language to the extent required for property valuation. Foreign language skills increase real estate valuers' performance on a globalizing market and enable them to flexibly respond to changes in the demand for valuation services.

11. Valuers who have strong interpersonal skills and are familiar with modern promotional and negotiation strategies are more likely to succeed on the modern real estate market.

12. Training curricula and continuing education programs for real estate valuers should also include a code of ethics for professional valuers to prevent an erosion of the property appraisal profession.

\section{Conclusions and Recommendations}

The main goal of this article to present the profile of a modern real estate valuer who has the required professional skills and competencies and is able to respond to uncertainty resulting from the rapid evolution of the real estate market and changes in the market environment. This goal has been achieved.

The recommended topics of instruction in the curricula of training programs for modern property 
valuers have been formulated based on a detailed analysis of the existing educational systems as well as the insights and opinions voiced by members of the professional community. These constructive suggestions should be critically analyzed by the responsible educational authorities in different countries.

The urgency of modernizing the curriculum with specific subjects depends on the education acquired as part of high school or university studies by applicants for real estate appraisal qualifications, or by persons who already have such qualifications.

So, as a rule, the formulation of a specific study / training / exercise program should take place under the needs of a specific group of people. Also the number of hours of lectures and classes should include the scope of knowledge and skills that a given property appraiser should possess or improve.

Property valuers who already have professional qualifications (e.g. granted in Poland by the competent minister) should broaden their knowledge and skills at the first in the field of Investment portfolio theory and property valuation for real estate investment (item no 5 from the list of subjects ). It seems, those who have engineering education in the field of geographical information systems should supplement their knowledge in functioning models of real estate markets (item No. 1 from the list). Economists by education usually have to acquire skills related to innovative valuation techniques and decision support systems (item no 7).

However, regardless of local regulations and customs, the skills and knowledge required for accessing, processing and correctly interpreting information about the real estate market and the attributes of various types of property will become mandatory for real estate valuers in the near future. The results of the study validate the research hypothesis which postulates that training curricula should be restructured and modernized to enable property valuers to identify and examine the relationships between market participants and the increasingly complex market environment and to determine the influence of these relationships on the value of property with the use of modern analytical methods and data processing tools.

Valuers who can flexibly respond to changes on the real estate market will be also better prepared to cope with fluctuations in the demand for specific services in a given market segment. The proposed topics of instruction can stimulate sustainable professional growth of property appraisers. Valuers can also indirectly contribute to sustainable economic growth by furthering their knowledge of the mechanisms underpinning the real estate market, identifying and accounting for these factors (such as the impact of energy efficiency on the value of property) in the appraisal process.

For this reason, the proposed changes in the curricula of real estate valuation programs can be applied universally to bring the skills and knowledge of property appraisers to modern standards. For these topics to be incorporated into a larger training framework, the programs and courses offered by universities should be adapted to specific market needs and the expectations of market participants in a given country (subject, thematic scope, teaching sequence, number of instruction hours).

Due to the highly unique character of the real estate market and the responsible role of property valuers, new curricula should be developed and implemented upon consultation with government agencies, professional organizations and market participants. Uniform standards of professional appraisal practice have not been introduced globally to date, and the modernization of training curricula should facilitate the harmonization of modern valuation principles around the world. The training curricula proposed in this article should increase property valuers' competencies and effectively support real estate market entities and sustainable urban development.

Funding: This work was supported by the National Science Centre [grant number 2019/33/B/HS4/00072]

\section{References}

Achu, K. (2013). Client Influence on Property Valuation: A Literature Review. International Journal of Real Estate Studies, 8(2), 24-47.

Act. (1997). Ustawa z dnia 21 sierpnia 1997 r. o gospodarce nieruchomościami (Act of 21 August 1997 on real estate management) (Dz. U. 1997 nr 15 poz. 741 z późn. zm.).

Act. (2012). Property and Business Valuation Methodology, approved by the order of the Minister of Finance of the Republic of Lithuania, 27 April 2012, no 1k-159, Official Gazette Valstybés Żinios, 2012-04-28, No 50-2502. 
Adair, A., Downie, M. L., McGreal, S., \& Vos, G. (2012). European valuation practice - theory and techniques. Oxford: Taylor \& Francis Group, 353.

Appraisal Institute. (2013). The appraisal of real estate (14th ed.).

Ball, M., Lizieri, C., \& MacGregor, B. (1998). The Economics of Commercial Property Markets. Routledge.

Barkham, R., Carve, S., Mellot, D., \& Schoenmaker, D. (2017). Globalization and Real Estate: Where next? CBRE Group. Switzerland https://www.cbre.es/$\angle$ media/cbre/countryspain/documents/research/golbal/globalization\%20and\%20real\%20estate. pdfAccessed 23 April 2020.

Blass, E. (2016). The future role of 'the property professional' - is there a role for a valuer? https://www.api.org.au/sites/default/files/uploaded-content/websitecontent/20160912_future_the_future_role_of_the_property_professional.pdf. Accessed 23 April 2020.

Brzezicka, J., \& Wiśniewski, R. (2014). Identifying selected behavioral determinants of risk and uncertainty on the real estate market. Real Estate Management and Valuation, 22(2), 30-40. https://doi.org/10.2478/remav-2014-0015

Coyle, M. L. (2015). Future of Valuation, Working RE magazine, http://www.workingre.com/futureof-valuation2/. Accessed 23 April 2020.

Der Beleihungswert-nachhaltigkeit seit 1900. (2017). Verband Deutscher Pfandbriefbanken, https://www.hypzert.de/sites/default/files/files/2019-09/vdp-beleihungswert_nachhaltigkeit2017-de.pdf. Accessed 23 April 2020.

EVS European Valuation Standards. (2018). The European Group of Valuers Associations (TEGoVA).

French, N. (2017). Professor Nick French presents the art of real estate valuation. European Valuer, 7.

Frydman, R., \& Goldberg, M. D. (2009). Ekonomia wiedzy niedoskonałej (The economics of imperfect knowledge). Imperfect Knowledge Economics, Wydawnictwo Krytyki Politycznej.

Grover, R. (2016). Mass valuations. Journal of Property Investment \& Finance, 34(2), 191-204. https://doi.org/10.1108/JPIF-01-2016-0001

Hannah, J. (2006). The Surveying Profession and its Skills Crisis. Proceedings $5^{\text {th }}$ Trans-Tasman Surveyors Conference, Cairns, Australia.

Hefferan, M. J. (2011). Changing demands for property professional service and its impact on tertiary courses - an Australian study. 17 th Pacific Rim Real Estate Conference, Gold Coast, Australia, 16-19 January.

Hockuba, Z. (2001). Nowa ekonomia instytucjonalna - czy zdominuje nasze myślenie w rozpoczynającym się stuleciu (New institutional economy - will it dominate our thinking in the beginning century). W A. Wojtyna (red.), Czy ekonomia nadąża za wyjaśnieniem rzeczywistości (Does economics keep up with the explanation of reality). VII Kongres Ekonomistów Polskich. PTE.

Hughes, W., \& Hughes, C. (2013). Professionalism and professional institutions in times of change. Building Research and Information, 41, 28-38. https://doi.org/10.1080/09613218.2013.737096

Islam, M. A. (2017). Future of Accounting Profession: Three Major Changes and Implications for Teaching and Research, IFAC, https://www.ifac.org/knowledge-gateway/preparing-futureready-professionals/discussion/future-accounting-profession-three. Accessed 23 April 2020.

IVS International Valuation Standards. (2020). International Valuation Standards Council (IVSC).

Jacobs, M. (2019). 7 Skills That Real Estate Appraisers Need. https://www.appraisersidekick.com/7skills-real-estate-appraisers-need/. Accessed 24 April 2020.

Kauko, T. J. (2013). Educational Aspects of Residential Value Analysis Methodology, Norwegian of Science and Technology, In Future Challenges for International Real Estate Education and Practice in 21 $21^{\text {st }}$ Century European Economies. ERES: Education Seminar. Bratislava, Slovakia, https://eres.architexturez.net/doc/oai-eres-id-eres2013-edu-106. Accessed 24 April 2020.

Keogh, G., \& D’Arcy, E. (1999). Property Market Efficiency: An Institutional Economics Perspective. Urban Studies (Edinburgh, Scotland), 36(13), 2401-2414. https://doi.org/10.1080/0042098992485

Kishore, R. (2004). Theory of Behavioural Finance and its Application to Property Market: A Change in Paradigm. Twelfth Annual Pacific Rim Real Estate Society Conference, January 22-25, Auckland, New Zealand, University of Western Sydney. 
Klamer, P., Bakker, C., \& Gruis, V. (2018). Complexity in valuation practice: An inquiry into valuers' perceptions of task complexity in the Dutch real estate market. Journal of Property Research, 35(3), 209-233. https:// doi.org/10.1080/09599916.2018.1510429

Kucharska-Stasiak, E. (2014). Reproduction of the real estate valuation methodology in practice. An attempt at identifying sources of divergences. Real Estate Management and Valuation, 22(2), 67-79. https://doi.org/10.2478/remav-2014-0018

Kucharska-Stasiak, E., \& Źróbek, S. (2015). An attempt to exemplify the economic principles in real property valuation. Real Estate Management and Valuation, 23(3), 5-13. https://doi.org/10.1515/remav-2015-0020

Kucharska-Stasiak, E., Źróbek, S., \& Cellmer, R. (2018). Forms and Effectiveness of the Client's Influence on the Market Value of Property - Case Study. Real Estate Management and Valuation, 26(3), 82-92. https://doi.org/10.2478/remav-2018-0027

Lorenz, D. (2006). The Application of Sustainable Development Principles to the Theory and Practice of Property Valuation. Universitäts Verlag Karlsruhe., https://doi.org/10.5445/KSP/1000005408

Mazzucato, M. (2018). The Value of Everything. Making and Taking in The Global Economy. Hachette Book Group.

Mooya, M. M. (2015). The education and professional practice of valuers in South Africa: A critical review. Property Management, 33(3), 245-274. https://doi.org/10.1108/PM-04-2014-0021

Renigier-Biłozor, M., \& Biłozor, A. (2016). Information capacity database in the rating model for Polish and Italian real estate markets. Real Estate Management and Valuation, 24(3), 40-51. https://doi.org/10.1515/remav-2016-0020

Renigier-Biłozor, M., Janowski, A., \& d'Amato, M. (2019). Automated Valuation Model based on Fuzzy and Rough Set Theory for Real Estate Market with Insufficient Source Data. Land Use Policy, 87(104021). https://doi.org/10.1016/j.landusepol.2019.104021

Report. (2015). Drivers for Change: Strengthening the Role of Valuation Professionals in Market Transition. RenoValue Market Insights Report, https://www.buildup.eu/en/news/driverschange-strengthening-role-valuation-professionals-market-transition-renovalue-market. Accessed 24 April 2020.

RICS. (2002). Property Valuation the Carsberg Report.

RICS. (2015). Our changing world: let's be ready. https://www.linkedin.com/pulse/our-changingworld-lets-ready-new-report-released-today-daniel-cook. Accessed 24 April 2020.

RICS. (2016). Automated Valuation Models (AVMs) - Opportunity or Threat? https://academy.rics.org/web-classes/residential-property/automated-valuation-modelsopportunity-or-threat. Accessed 24 April 2020.

RICS. (2017). The Future of Valuations. The relevance of real estate valuations for institutional investors and banks - views from a European expert group, https://anavaliadores.pt/wpcontent/uploads/2018/04/RICS-Future-of-Valuations-insights-paper.pdf. 27-35. Accessed 24 April 2020.

RICS. (2020). Impact of COVID-19 on valuation https://www.rics.org/globalassets/ricswebsite/media/upholding-professional-standards/sector-standards/valuation/impact-of-covid19-on-valuation-vn2.pdf. Accessed 24 April 2020.

Ring, A., \& Dasso, J. (1989). Real Estate Principles and Practices. Prentice Hall PTR.

Runde, T. P. (2015, Spring). Net Zero Energy Buildings: An Introduction for Valuation Professionals. The Appraisal Journal, 141-148.

Sarazen, P. (1995). Highest and best use of a vacant parcel. The Appraisal Journal, 63(3), 281.

Savills. (2016). Around The World In Dollars And Cents - 2016. (2016). What price the world. Trends in international real estate trading, Savills world research 2016, http://www.savills.co.uk/research_articles/229130/198667-0. Accessed 24 April 2020.

Savills. (2018). 8 things to know about global real estate value | https://www.savills.com/impacts/market-trends/8-things-you-need-to-know-about-the-valueof-global-real-estate.html. Accessed 24 April 2020.

Susskind, R., \& Susskind, D. (2015). The future of the professions: How technology will transform the work of human experts, 346. Oxford University Press. https://doi.org/10.1093/oso/9780198713395.001.0001

TEGoVA. (2020). Valuation During the Pandemic. https://www.tegova.org/en/p5e78ef30d01d7. Accessed 24 April 2020. 
Thorne, C. (2012). Valuation: The professional challenge. Journal of Property Investment E Finance, 30(4), 4. https://doi.org/10.1108/jpif.2012.11230daa.001

Wilkinson, S., Antoniades, H., \& Halvitigala, D. (2018). The future of the Australian valuation profession: New knowledge, emerging trends and practices. Property Management, 36(3), 333-344. https://doi.org/10.1108/PM-04-2017-0026

Wilkinson, S., Halvitigala, D., \& Antoniades, H. (2017). The Future of the Valuation Profession. In Australia API Final Report.

Williamson, I., \& Wallace, J. (2007). Building Land Markets in the Asia Pacific Region. Paper delivered to international workshop on Good Land Administration - Its Role in Economic Development. Ulaanbaatar, Mongolia. https://www.researchgate.net/publication/228827314_Building_land_markets_in_the_Asia_Pacif ic_region. Accessed 24 April 2020.

Wolverton, M. L. (2000). Self-Perception of the Role of the Appraiser: Objective Opinions or Price Validations? The Appraisal Journal, 68(3), 272-282.

Zissler, M. (2016). Things have to change to stop the Valuation industry cannibalising itself. https://www.api.org.au/news/things-have-to-change-to-stop-the-valuation-industrycannibalising-itself. Accessed 24 April 2020.

Źróbek, S., \& Grzesik, C. (2013). Modern Challenges Facing the Valuation Profession and Allied University Education in Poland. Real Estate Management and Valuation, 21(1), 14-18. https://doi.org/10.2478/remav-2013-0002

Źróbek, S., Kucharska-Stasiak, E., Naimaviciene, J., \& Tupenaite, L. (2016). Selected aspects of real estate appraisers' professional training on the background of economic theory. Journal of International Students, 9(2), 150-157. https://doi.org/10.14254/2071-8330.2016/9-2/11 